\title{
The Effect of Covid-19 on BIST-100 and Exchange Rates Influencing Businesses
}

\section{Covid-19'un Isşletmeleri Etkileyen BIST-100 ve Döviz Kurlarına Etkisi}

\author{
Mehmet İslamoğlua ${ }^{\mathrm{a}}$, Muhammed Ali Yetgin ${ }^{\mathrm{b}, * *}$, Fatih Kayhan $^{\mathrm{c}}$ \\ a Assoc.Prof.Karabuk University, Faculty of Business, Department of Finance and Banking, Karabuk / Turkey. \\ ORCID ID: 0000-0002-4416-0888 \\ ${ }^{\mathrm{b}}$ Asst. Prof., Karabuk University, Vocational School of Social Sciences, Department of Social Work and Counseling, Karabuk / Turkey. \\ ORCID ID: 0000-0002-8120-4704 \\ ${ }^{\mathrm{c}}$ Asst. Prof., Kırklareli University, Faculty of Applied Sciences, Department of Finance and Banking, Kırklareli / Turkey. \\ ORCID ID: 0000-0001-7844-8663
}

\section{MAKALE BİLGISİ}

Makale Geçmişi:

Başvuru tarihi: 20 Temmuz 2020

Düzeltme tarihi: 16 Şubat 2021

Kabul tarihi: 23 Şubat 2021

Anahtar Kelimeler:

Sosyal Kaytarma

Analitik Hiyerarşi Prosesi (AHP)

Akademik Personel

\section{ARTICLE INFO}

Article history:

Received 20 July 2020

Received in revised form 16 Februray 2021

Accepted23 February 2021

Keywords:
Social Loafing
Analytic Hierarchy Process (AHP)
Academic Staff

\begin{abstract}
A B S T R AC T
Covid-19, appearing first in City of Wuhan in People's Republic of China in December 2019, infected all continents, regions and countries in a very short period. Covid-19 influenced the humanity in terms of health, economic and social aspects. The effect of Covid-19 on the economy is studied in this research. Businesses are considered as one of the most important actors of the country's economy. Investments in stocks, stock exchange and exchange rates determine the activities of businesses. The effects of Covid-19 pandemic on exchange rates (USD/TL and EURO/TL) and Borsa Istanbul (BIST-100) are examined in this study. E-views 9.0 statistical program is used in this research. Phillips-Perron unit root test and multiple regression tests are employed in the analyses. The study concludes by suggesting that Covid-19 daily number of cases and number of patients that recover the pandemic have significant effect on USD/TRY, EUR/TRY and BIST-100, which are leading economic and financial indicators as far as Turkey is concerned.
\end{abstract}

ÖZ

2019 yılı aralık ayında Çin Halk Cumhuriyeti'nin Vuhan kentinde ortaya çıkmış olan Covid-19 pandemisi kısa bir süre içinde tüm kıta, bölge ve ülkelere yayılmıştır. Covid-19 virüsün sağlık, ekonomik ve sosyal etkileri olmuştur. Bu çalışmada Covid-19'un ekonomiye etkisi yönü araştırılmaktadır. Ülke ekonomisinin en önemli aktörlerinin başında ticari işletmeler gelmektedir. Ticari işletmelerin faaliyetlerinin ölçümünde döviz kurları ve borsadaki yatırım seviyelerinin önemli etkenler olduğu bilinmektedir. Bu çalışmada Covid-19 pandemisinin, ülkemiz işletmeleri için önemli barometrelerinden olan döviz kurlarına (USD ve EURO) ve işletmelerin yatırım gördüğü BIST-100'e etkileri incelenmiştir. Araştırmada E-views 9.0 istatistik paket programı kullanılmıştır. Phillips-Perron birim kök test analizlerinden ve çoklu regresyon analizlerinden yararlanılmıştır. Covid-19 günlük vaka sayısı ve iyileşen hasta sayısının; Türkiye'deki işletmeler için hayati barometreler olan USD, EURO ve BIST-100'e anlamlı etkilerinin olduğu görülmüştür.

\section{Introduction}

Throughout history, humanity has encountered various pandemics many times. One of the deadliest pandemics of the 20th century was considered to be the 'Spanish flu'. At the time of the SARS virus, Dr. Alison McGeer (epidemiologist at Toronto's Mount Sinai Hospital) stated that "We were warned, the next pandemic is likely to be much more contagious and perhaps more lethal than SARS" (Gupta et al., 2005: 392). There is not enough information

\footnotetext{
** Sorumlu yazar/Corresponding author

e-posta: m.ali.yetgin@karabuk.edu.tr
} 
known about the medium and long term macroeconomic effects of global pandemics. (Jorda et al., 2020: 1). However, the measurement of economic declines caused by the Covid19 outbreak was one of the urgent issues (Jorda et al., 2020: 1). Covid-19, a member of the coronavirus family such as SARS and MERS, caused a disruption in the global economic activity apart from its being a deadly pandemic. In this way, it has caused countries to face many problems politically, economically and socially. There have been short term and significant declines in real returns in stocks and short-term government bonds as in the case of the Spanish flu of 1918-1920 (Barro et al., 2020: 17).

The power of businesses plays an important role in the development and wealth of a country. Efficiency and profitability of national and international businesses relate to values of various financial instruments / indicators. In this research, the effect of the number of Covid-19 daily new case and the number of recovering patients on exchange rates and BIST-100, leading financial indicators as far as Turkey is concerned. The variations in exchange rates (Usd/Try; Euro/Try) have remarkable effect on import and export of businesses (foreign trade companies). Similarly, the status of changes in the BIST-100 index may affect the course of investments for the businesses (publicly-traded companies) whose shares are traded in Borsa Istanbul.

The main purpose of this study is to examine the impact of Covid-19 on various financial indicators/tools in order to observe the financial status of publicly-traded businesses that make contribution to the economy of Turkey during the pandemic. The contribution of this study to the literature is that it will help understand the effect of a pandemic on leading financial indicators/tools in the face of Covid-19 being a new pandemic and that the lack of adequate studies on this subject in the literature. Especially, it has been observed that there are not enough studies on the effect of coronavirus on exchange rates for Turkey which makes this study unique one.

\section{Literature Review}

\subsection{Pandemic and Covid-19}

When the origin of the word pandemic is examined, it is known that the word "pan" in Greek is defined as "all" and the word "demos" is defined as people, today it is defined as a general name for epidemics that spread across the world (Türkiye Bilimler Akademisi, 2020: 20). The degree of influence of pandemic on people depends on the power of the pandemic, the immunity of the society, the life habits of individuals and the risk factors that it carries in the working life, the facilities of the country's health conditions and the characteristics of the climate (Türkiye Bilimler Akademisi, 2020: 20). In the 21 st century, humanity has encountered some epidemic diseases. H1N1 seen in 2003 and H5N1 seen in 2009, one of the subtype viruses of Influenza, were among the important pandemics affecting the world (Smith, 2009:1). The rapid spread of H5N1 flu and the inability to develop an effective vaccine led to a worldwide fear of pandemics (Jonung, 2006: 4). Various discussions were made about the danger of the emergence of a new flu that hit the world with the avian influenza outbreak common in Asia, Africa and Europe (Ewers, 2007: 1). SARS coronavirus, which is known to spread from the Guangdong Province of the People's Republic of China between 2002-2003, was found to infect 8422 people in China and cause 916 deaths; the MERS-CoV epidemic, which was seen for the first time in Saudi Arabia, was found to be transmitted from the batsourced camel, 2494 people were infected and 858 people died; clinical and vaccination studies for SARS and MERS, which are in the coronavirus family, have continued, but sufficient information about the pathogen of the virus has not been obtained yet (Türkiye Bilimler Akademisi, 2020: 15).

In December 2019, a new type of virus from the coronavirus family appeared in the city of Wuhan, the capital of the Hubei state of the People's Republic of China and it is defined as SARS-CoV2 or Covid-19; the virus soon spread to Europe, North America, Asia-Pacific countries and the whole world and was declared as a virus pandemic by the World Health Organization (Aslan, 2020: 39).

The fact that the disease was transmitted to 59 thousand people at the end of ten cycles formed by the transmission of all three people to the other three people showed that it was a rapidly spreading pandemic. (Aslan, 2020: 39). As of 5 June 2020, Covid-19 infected 6,515,796 people and killed 387,298 people in 216 countries (World Health Organization, 2020). In response to the Covid-19 pandemic, countries around the world have implemented various public health and social measures, including social distance, closure of schools and businesses, geographic quarantine and mobility restrictions; as the local epidemiology of the disease changes, countries have announced to adjust and restore these measures accordingly; The World Health Organization issued an intermediate guidance document on 16 April 2020, which advised on adjusting public health and social measures while managing the risk of re-emergence (WHO Report, 2020: 1).

\subsection{Pandemics and Their Effects on Economies}

The effects of illness and death rates in influenza pandemics experienced in the past years have had a significant impact on the economy, and it has been observed that there is a decrease in labor and quality, including labor supply (Smith, 2009:1). In the pandemic period, it was observed that various factors such as production loss and absenteeism create indirect costs. (Yoldascan et al., 2010: 140). In addition, the severity of the disease was shown to cause a 0.5 to $4.3 \%$ reduction in domestic production in the respective countries (Smith, 2009:5). It was observed that the SARS epidemic that occurred in 2003 affected the economies remarkably, while the effects of $\mathrm{H} 1 \mathrm{~N} 1$ and $\mathrm{H} 5 \mathrm{~N} 1$ influenza pandemics were stronger (Keogh-Brown, 2010: 543). SARS has brought about a short but sharp decline in the Chinese economy, causing slow growth in exports, high inventories, increased employment pressure, and causing small and medium-sized enterprises to suspend the activities, but did not affect the investment of foreign investors in the country (Rawski, 2005:9). With the outbreak of the H5N1 pandemic in 2006, Turkey faced mass poultry slaughter (Yoldascan et al., 2010: 140). The rapid spread of HIV, especially in South Africa, South and Southeast Asia and the Caribbean, has shown that it poses a major threat to the social and economic structure of many countries and thus to their survival (Altman, 1999: 579). Brahmbhatt (2005) argues that according to the estimates made by the World Bank in 
revious years, a global flu epidemic was declared to have a loss of at least 800 billion dollars to the world economy, long-term costs of today's flu pandemics are predicted to be much higher (Garrett, 2008: 75).

\subsection{The Impact of Covid-19 on Economy}

It is understood from the studies conducted in the literature that the recent coronavirus has a direct impact on the economies, commercial companies, financial institutions and organizations of many countries in the world. It was stated that the outbreak does not only effect health, its economic effects are also worrying; in the preparation for the epidemic, measures should be taken in two key areas, which are health and economic aspects, accordingly, the protection of the social distance and the commitment to continue to work with the understanding of continuing business is emphasized (Smith, 2009:1). During this period, the importance of taking the right steps in the use of vaccines and antivirals was also considered among the things to be done (Smith, 2009:1). It was stated that the conceptualization of the financial shock as a form of 'contagion' will cause fear and expectations in the society and therefore affect financial policy, and panic together with volatility can be triggered proportionally (Peckham, 2013: 242). It was stated that a possible lack of coordination in quarantine application may carry the risk of re-spread of the virus again, and that if these limitations cover a very long process, this may put a heavy burden on macroeconomic economic activities (Kohlscheen, 2020: 6).

Covid-19 was seen as an epidemic that could seriously change and affect human health and psychology as well as the global economy, society's view of events and their approach to education, economy, profession and work, and thus their lifestyle (Aslan, 2020 :41). The world debt stock caused by this virus was found to be well above the level of the Great Depression that took place in 1929; it is considered late in predicting the results of the central banks' emergency measures and their short-term moves in the long term (ULISA, 2020: 29). For this reason, it is stated that the world economies have a very fragile structure with the effect of the demand and supply shock and oil price shocks caused by the epidemic (ULISA, 2020: 29). In China, where coronavirus first appeared, industrial production, sales and investment fell in the first two months of the year compared to the same period of (Abodunrin, 2020: 20). Before the epidemic, looking at the Canadian economy, GDP growth was only increasing at an annual rate of $2 \%$ or less, while growth was only $0.3 \%$ after the outbreak of the disesase, and the trend in productivity and real wages was similarly slow (Williams, 2020: 9). Germany has taken unprecedented measures to reduce coronavirus pandemics, accordingly, federal and state governments took several drastic measures to slow the country's rising coronavirus infection rate (Covid-19) (Abodunrin et al., 2020: 21). The African Development Bank has announced health and safety measures to help prevent the spread of coronavirus in countries where it is observed (Abodunrin et al., 2020: 21). Due to some restrictions created as a result of the emergence of coronavirus pandemics, the US dollar fell against some important currencies (Bloomberg, 2020).

Turkey seems advantageous, because of the condition of medium and long-term textile industry in China, the industry may forward operations to Turkey slowly (ULISA, 2020: 29). Electricity consumption between March 10, 2020 and April 12, 2020, compared to the same period of 2019 decreased by $5.64 \%$ (the average electricity consumption of the period), the reason for this is the stagnation of industrial production, commercial activities, public services and formal education services after Covid-19 (ULISA, 2020: 8). Measures taken for Covid-19 in Turkey caused some disruption in commercial activities, some fluctuations in prices and exchange rates; on the other hand the measures taken in developed countries led to significant reduction in long-term interest rates (KPMG International Cooperative NL, 2020). The reflection of the disease on the BIST, BorsaIstanbul, Turkish Stock Market is explained as follows; as far as publicly owned companies traded in Borsa-Istanbul is concerned, the disease affected industries' returns and volatility which is the most basic indicator of financial asset riskiness and the uncertainty in price changes (Peker ve Demirhan, 2020:7). (Export) Rediscount loans are redesigned / provided by Central Bank of Turkey within the context of measures taken against the influences of pandemic (Istanbul Sanayi Odas1, 2020: 5). Thus, TL-denominated export and foreign currency-earning services rediscount credits were implemented in order to ensure that the companies exporting the goods and services have easy and fast access to the financing they need and to support the continuity of employment (Istanbul Sanayi Odas1, 2020: 5). The total limit of the loans to be extended was determined as TL 60 billion, it was decided that at least seventy percent of the loans to be extended through banks other than Eximbank would be given to small and medium enterprises (SME) (ISO, 2020: 5). It is suggested that the preparations should be carried out completely for the possible repetition of the epidemic, the public expenditures that directly take care of the needs of the households and companies should be made, and monetary and fiscal policy instruments should be used effectively (ULISA, 2020: 29).

In a study, it was observed that the effect of coronavirus on Borsa Istanbul was statistically significant (Yetgin, 2020: 334). According to the correlation result of the study covering the period between March 10 and April 21, it was observed that an increase in the number of coronavirus cases caused an increase of 0.63 units in the Stock Exchange (Yetgin, 2020: 331). In different periodical times, there were decreases in the value of Borsa İstanbul (Kılıç, 2020: 76). In one of another studies on Borsa Istanbul in the literature, it was seen that the electricity, transportation, financial, industry and technology sectors were economically exposed to significant effects from the Covid-19 outbreak, while no significant effects were achieved in the food-beverage, trade, textile, tourism and ervices sectors (Tayar etc, 2020: 310). In a study, it was seen that the coronavirus seriously affected the metal, machinery, sports, tourism and insurance sectors, and had little effect on the food, wholesale and retail sectors (Öztürk etc., 2020: 68).

\section{Data and Methodology}

In this study, whether the number of coronavirus cases and the number of recovering patients (Covid-19) had a significant effect on Borsa İstanbul and exchange rates (EUR/TRY and USD/TRY) is examined. 
Table 1. Definition of the Variables

\begin{tabular}{|c|c|c|c|}
\hline $\begin{array}{c}\text { Name of the } \\
\text { Variables }\end{array}$ & $\begin{array}{l}\text { Type of the } \\
\text { Variables }\end{array}$ & Definition & Resource \\
\hline LNCase & Independent & $\begin{array}{l}\text { The number } \\
\text { of daily cases } \\
\text { of Covid-19. }\end{array}$ & \multirow{2}{*}{$\begin{array}{c}\text { Ministry of } \\
\text { Health of } \\
\text { Turkey, } \\
\text { official web } \\
\text { site. } \\
\text { https://covid } \\
\text { 19.saglik.go } \\
\text { v.tr/ }\end{array}$} \\
\hline LNRecovered & Independent & $\begin{array}{l}\text { The number } \\
\text { of recovering } \\
\text { patients from } \\
\text { Covid-19. }\end{array}$ & \\
\hline EURO/TRY & Dependent & $\begin{array}{l}\text { Euro Value of } \\
\text { Turkish Lira } \\
\text { (Exchange } \\
\text { Rate) }\end{array}$ & \multirow{3}{*}{$\begin{array}{c}\text { Investing.co } \\
\text { m Media } \\
\text { Co. } \\
\text { tr.investing. } \\
\text { com }\end{array}$} \\
\hline USD/TRY & Dependent & $\begin{array}{c}\text { American } \\
\text { Dollar Value } \\
\text { of Turkish } \\
\text { Lira } \\
\text { (Exchange } \\
\text { Rate) }\end{array}$ & \\
\hline BIST 100 & Dependent & $\begin{array}{c}\text { Borsa Istanbul } \\
\text { (Istanbul } \\
\text { Stock } \\
\text { Exchange) }\end{array}$ & \\
\hline
\end{tabular}

Research Model is shown in Figure 1.

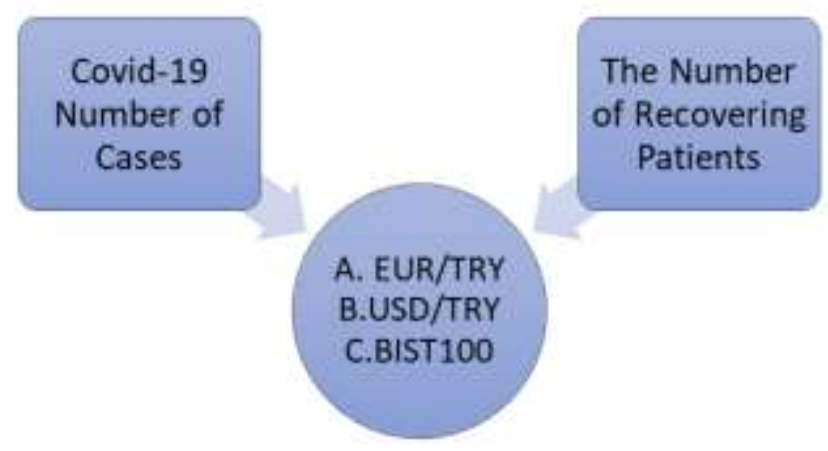

Figure 1. Research Model

Research hypotheses are as follows:

Ho: The number of coronavirus cases and the number of recovering patients have no significant effect on the Euro/Try rate.

$\mathbf{H}_{1}$ : The number of coronavirus cases and the number of recovering patients have significant effect on the Euro/Try rate.

$\mathbf{H}_{\mathbf{0}}$ 1: The number of coronavirus cases and the number of recovering patients have no significant effect on the Usd/Try rate.

$\mathbf{H}_{11}$ : The number of coronavirus cases and the number of recovering patients have significant effect on the Usd/Try rate.

Ho_2: The number of coronavirus cases and the number of recovering patients have no significant effect on BIST-100.

H22: The number of coronavirus cases and the number of recovering patients have significant effect on BIST-100.

Limitations of the study is the number of daily coronavirus and the number of cases in Turkey and recovering patients, which is provided by the Ministry of Health. Another limitation is the daily BIST 100, American Dollar/Turkish Lira and Euro/Turkish Lira data published by Borsa İstanbul (BIST), Turkish Central Bank. Another limitation of the study is that the data set belongs to the dates between 10 March 2020 and 22 May 2020. The data were obtained from the official websites announced by the Ministry of Health and Borsa Istanbul to the public.

Data in the research is analyzed by using E-views 9.0 Statistical Program.

It is necessary that the variables to be used in the analysis must be stationary. Because if the time series are not stationary, they include stochastic or deterministic trends. In such a case, spurious regression condition might arise in the regression model where time series are used (İslamoğlu,2015:14). For this reason first of all Unit root analysis is conducted to test stationarity of variables at level. If the stationarity is not ensured at level then the data is transformed by taking difference. Multi regression analysis is performed using Ordinary Least Squares Method to see whether independent variables significantly affect dependent variable. As there are more than one independent variable in each regression model, the VIF values are calculated to test multicollinarity. And finally Cusum Test is conducted to detect instability where the cumulative sum goes outside the area between the two critical lines.

\section{Findings}

\subsection{Descriptive Statistics}

Descriptive statistics of the research can be seen in Table 2 .

Table 2. Descriptive Statistics

\begin{tabular}{|c|c|c|c|c|c|}
\hline & DEUR & DUSD & LNBST100 & LWVAKA & LNIYLESEN \\
\hline Hean & 0.005275 & 0.005223 & 11.46794 & 10.66675 & 8514503 \\
\hline Median & 0.000000 & 0.000000 & 11.49114 & 11.41839 & 9.505246 \\
\hline Havimum & 0.135000 & 0.122300 & 11.54272 & 11.94795 & 11.66230 \\
\hline Minimum & -0.165600 & -0.141400 & 11.34150 & 5.883322 & 0.693147 \\
\hline Std Der. & 0.053239 & 0.049508 & 0.056479 & 1.583728 & 3.111192 \\
\hline Skewness & -0.385656 & -0.162635 & -0.730799 & -1.448794 & -0.846130 \\
\hline Kustosis & 4.053034 & 4.311097 & 2192606 & 4.058828 & 2567438 \\
\hline Jarque-Bera & 4.613634 & 4.942101 & 7.551258 & 2577568 & 8.286424 \\
\hline Probability & 0.099578 & 0.084496 & 0.022923 & 0.000003 & 0.015872 \\
\hline Sum & 0.342900 & 0.339500 & 745.4160 & 693.3391 & 553.4427 \\
\hline Sum Sq. Dev. & 0.181398 & 0.156870 & 0.204149 & 160.5244 & 619.4891 \\
\hline Observations & 65 & 65 & 65 & 65 & 65 \\
\hline
\end{tabular}

Looking at the data in Table 2, the mean, mode, median values are close to each other, the skewness and the kurtosis value close to 0 within the limits of \pm 1 proved to be a normal data distribution.

\subsection{Unit Root Test Results}

In the study first of all, Unit root tests were applied for dependent and independent variables at level. If there is a unit root at level, we can infer that the data is not stationary. At that moment, we must transform data by taking difference until it becomes stationaryTable 3 includes unit root test results: 
Table 3. Unit Root Test Results

\begin{tabular}{ccccc}
\hline \multicolumn{5}{c}{ Philip Perron Unit Root Test Results (Constant (Invariant) and with- } \\
Trend) \\
\hline & R-squared & Adjusted R-squared & F-Statistic & Prob. \\
\hline EUR & 0.048309 & 0.021118 & 1.776637 & 0.8773 \\
\hline$\Delta$ EURO & 0.627483 & 0.616686 & 58.11332 & 0.0000 \\
\hline USD & 0.089913 & 0.063910 & 3.457841 & 0.8991 \\
\hline$\Delta$ USD & 0.550253 & 0.537217 & 42.20979 & 0.0000 \\
\hline LNBIST100 & 0.197171 & 0.174233 & 8.595822 & 0.0201 \\
\hline LNCase & 0.795208 & 0.789095 & 130.0808 & 0.0001 \\
\hline LNRecovered & 0.673026 & 0.662305 & 62.77954 & 0.0790 \\
\hline
\end{tabular}

Unit root analysis was performed for Euro/Try, which is a dependent variable, by using Phillips-Perron (Phillips, 1988) Test as per Constant and Trend. According to test results, the Euro/Try data was not stationary at level but when the data was transformed by taking first difference, it became stationary. Similarly Unit root analysis was performed for Usd/Try, which is another dependent variable, by using Phillips-Perron Test. The Test Results revealed that the Usd/Try data was not stationary at level as well. In order to ensure stationarity, the data is transformed by taking first difference both Eur/Try and Usd/Try becomes stationary after taking their first differences at $\% 1$ significance level

Unit root analysis was performed for the last dependent variable, BIST-100, by using Phillips-Perron Test. According to test results, BIST-100 data was found to be stationary at level. However significance level of BIST-100 data is $\% 10$ according to the test results.

As for the independent variables, 'the number of Covid-19 cases'and 'the number of recovering patients', PhillipsPerron Test was conducted to examine stationarity at level. Both of the series were found to be stationary at level after performing the Test.

\subsection{Multiple Graphs of Equations}

The following graph illustrates the change in the number of recovering patients, Covid-19 cases and the exchange rate of Euro /Try. In the graphs, LNIYILESEN refers to LNRecovered while LNVAKA refers to LNCase.

Graph 1. Covid-19 and EUR/TRY

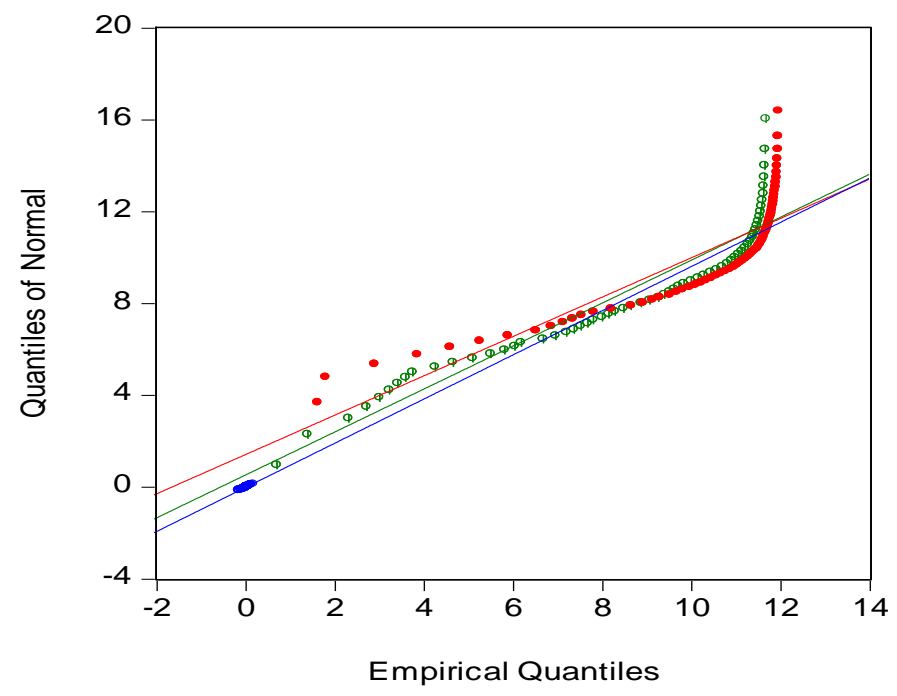

- DEUR - LNVAKA $\odot$ LNIYILESEN
According to Graph 1, it is seen that the Euro/Try rate does not seem to be significantly affected despite the increase in the number of coronavirus daily cases and the number of recovering patients with the same acceleration and subsequent stabilization.

Graph2 below shows the change in the number of recovering patients, Covid-19 cases and the exchange rate of Usd /Try. According to the Graph, it is clear that the Usd/Try rate does not seem to be significantly affected despite the increase in the number of coronavirus daily cases and the number of recovering patients with the same acceleration and subsequent stabilization

Graph 2. Covid-19 and USD/TRY

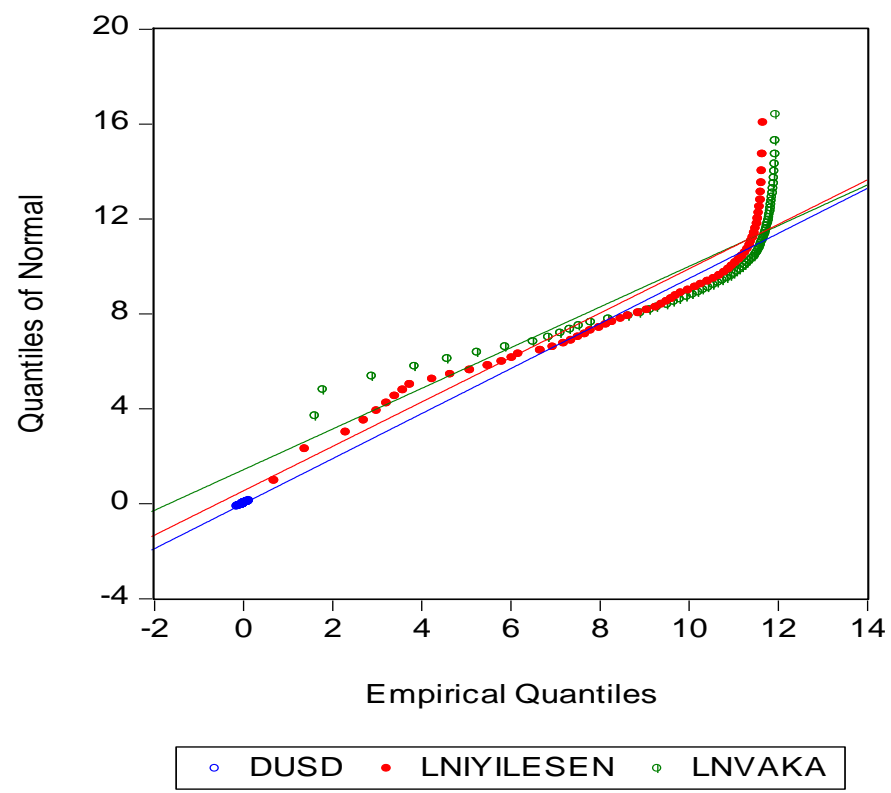

According to Graph 3, BIST-100 value is observed to have a more stable trend similar to the increase in the number of coronavirus daily cases and the number of recovering patients.

Graph 3. Covid-19 and BIST-100

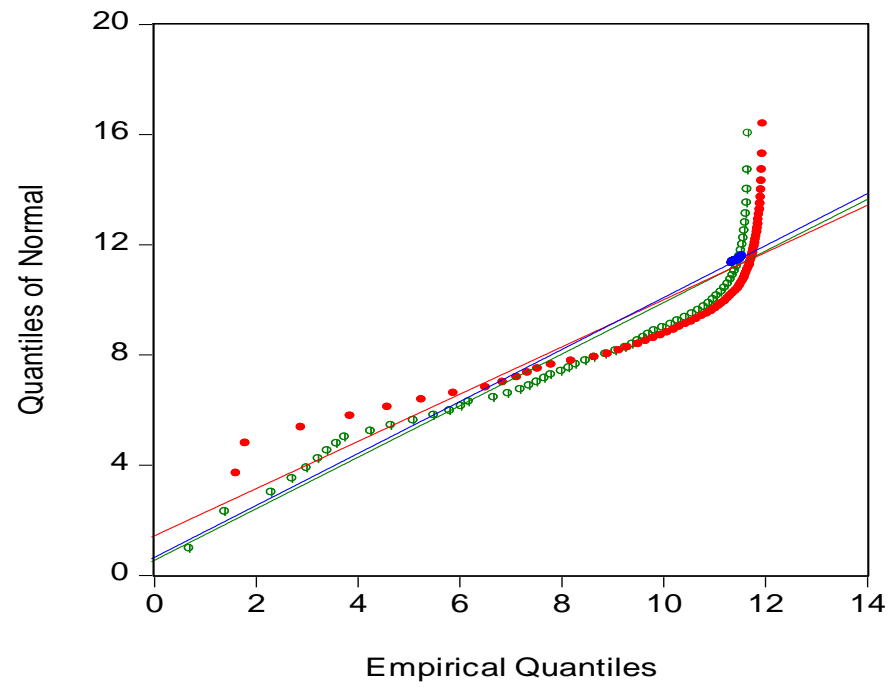

- LNBIST100 • LNVAKA $\odot$ LNIYILESEN 


\subsection{Regression Analyses}

In the research, multi-regression test was applied to analyze the relationship between dependent and independent variables. In statistical analysis, correlation analysis is conducted to examine the relationships between variables, and regression analysis is performed to make estimation for variables (Bursal, 2019:129).

Regression analyses results for dependent variables EUR/TRY, USD/TRY (exchange rates) and BIST-100, independent variables Covid-19 number of cases and number of patients that were recovered are shown in Table 4.

Table 4. Multi-Regression Analyses Results

\begin{tabular}{cccc}
\hline \multicolumn{4}{c}{ Least Squares Method } \\
\hline & \multicolumn{3}{c}{ Dependent Variables } \\
\hline & $\Delta$ EURO & $\Delta$ USD & LNBIST-100 \\
\hline LNCase & 0.042021 & 0.033928 & 0.000257 \\
\hline & $2.317030^{*}$ & $2.000325^{*}$ & 0.039342 \\
\hline LNRecovered & -0.022593 & -0.019047 & 0.017046 \\
\hline R Square & $-2.447299 *$ & $-2.206080^{*}$ & $5.1249999 * *$ \\
\hline $\mathrm{P}<0,01 * *, \mathrm{p}<0,05^{*}$ & 0.089309 & 0.078873 & 0.894963 \\
\hline
\end{tabular}

$\mathrm{P}<0,01 * *, \mathrm{p}<0,05^{*}$

In the table, the italic characters stand for t-statisticsand normal characters for coefficents.

Considering the coefficient values for the Euro according to Table 4, one unit increase in the number of daily cases causes an increase of 0.042021 in the Euro/Try exchange rate and one unit increase in the number of recovering patients decreases the rate by -0.022593 . Considering the coefficient values for the USD/TRY variable, one unit increase in the number of daily cases causes a increase of 0.033928 in the USD/TRY rate and ne unit increase in the number of recovering patients causes a decrease of -0.019047 in USD/TRY. Considering the coefficient values for BIST-100, an increase of 1 unit in the number of daily cases causes an increase of 0.000257 in the BIST-100 value, and an increase of one unit in the number of recovering patients leads to a increase of 0.017046 in the BIST-100 value. Considering the R-squared value of the EUR/TRY variable in Table 4, it is seen that the number of patients recovered and the number of Covid cases explained $8.93 \%$ of the change in EUR/TRY. Likewise, the R-squared value of the USD/TRY variable in Table 4, it is seen that the number of patients recovered and the number of Covid cases explained $7.88 \%$ of change in USD/TRY. On the other hand, the R-squared value of the BIST-100 variable in Table 4 , it is seen that the number of patients recovered and the number of Covid cases explained $89.49 \%$ of the exchange rate change in BIST-100. As the number of independent variables in the models are more than one, we must verify that there is no multicollinerity within the models. In order to check whether the multicollinearity problem exists, Variance Inflation Factor Values are calculated and presented in the table below.
Table 5. Variance Inflation Factors

\begin{tabular}{ccc}
\hline Variable & Coefficient & Centered \\
\hline & Variance & VIF \\
\hline LNRecovered & $3.04 \mathrm{E}-13$ & 4,65 \\
\hline LNCase & $1.79 \mathrm{E}-13$ & 4,65 \\
\hline
\end{tabular}

The Centered VIF Values above verify that there is no multicollinearity problem in the models as the VIF values of the independent variables are lower than 5. For Stability Diagnostics, we performed CUSUM Tests and subsequently extracted CUSUM Graphs for each dependent variable. According to Woodward ve Goldsmith (1964) CUSUM graphs are used to detect small shifts in the process average, to provide information on process correction, to determine from which sample the process average shift started, to estimate reliably the current process average and to make predictions about the future process average for the short term (Oktay and Ozçomak 2001: 362). CUSUM graph that indicates Euro/Try change in connection with the number of recovering patients and Covid-19 cases is indicated below. It is seen that the value of EUR / TRY variable does not go out of the red lines and there is no outliers.

\section{Graph 4. CUSUM (EUR/TRY) Graph}

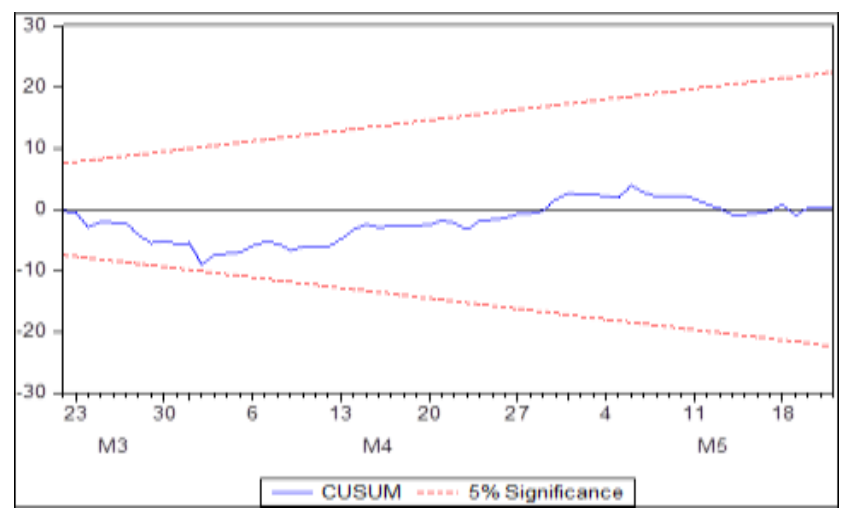

CUSUM graph that indicates Usd/Try change in connection with the number of recovering patients and Covid-19 cases is indicated below. It is seen that the value of USD / TRY variable does not go out of the red lines and there is no outliers.

Graph 5. CUSUM (USD/TRY) Graph

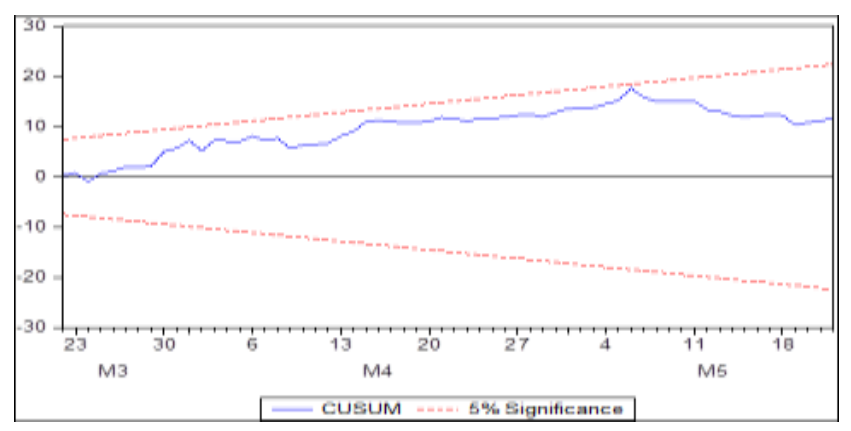

CUSUM graph that indicates BIST-100 change in connection with the number of recovering patients and Covid-19 cases is indicated below. It is seen that the value of BIST-100 variable does not go out of the red lines and there is no outliers. 
Graph 6. CUSUM (BIST-100) Graph

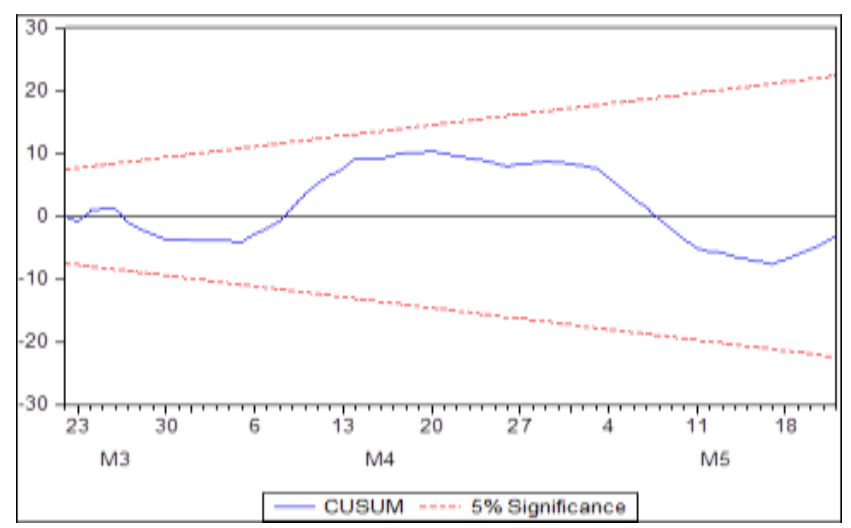

\section{Conclusion and Recommendation}

The countries' health and economic struggle related to coronavirus continues against the pandemic that spread to the whole world from China in December 2019. Due to Covid-19, multinational and local businesses operating in different sectors (in different) countries stopped their operations or had to go to a restriction. It is seen in the literature that businesses, that are valuable assets of countries, are affected by some financial instruments during pandemic. According to sectoral studies in the literature, coronavirus can affect some sectors positively and some sectors negatively. This situation brings periodic decreases and increases on BIST-100. In one of the researches about Borsa Istanbul index, Tofas company had been affected by Covid-19 negatively (Yetgin, 2020a: 313), while there was found no relationship between the index value of Logo Yazılım and virus cases (Yetgin, 2020a: 269).The difference of the effection of the companies by Covid-19, might be one of the reasons of the value of Borsa Istanbul.

It is known that exchange rates and Borsa-Istanbul affect the investment activities of companies. In this study, the effects of Covid-19's daily case number and daily improvement numbers on the exchange rates (Euro/Try and the US dollar/Try) and on BIST-100 where shares of many multinational companies are traded were examined.

Three hypotheses were established in the research. According to the results of the research, it was found that number of coronavirus cases and number of recovering patients had an significant effect on the Euro/Try. Due to the results, it was seen that the number of coronavirus cases and the number of recovering patients explained the change in the dependent variable of Euro/Try rate by $5 \%$. Another finding on the research was reported as the number of coronavirus cases and number of recovering patients had an significant effect on the Usd/Try rate. According to the results of the research, it was seen that the number of coronavirus cases and the number of recovering patients explained the change in the dependent variable of Usd/Try rate by $4 \%$. The last finding of the research had showed that number of coronavirus cases and number of recovering patients had an significant effect on the BIST-100 organization. The results indicate that $89 \%$ of the change in BIST-100, another dependent variable, can be explained by number of coronavirus cases and number of recovering patients.
Considering all these, it is concluded from the findings that Covid-19 has had significant impact on exchange rates (Euro/Try, Usd/Try) and BIST-100, that are considered to be leading indicators affecting businesses in Turkey. It is thought that this study will make a serious contribution to the literature since there are not enough studies on social sciences yet. Various studies are proposed on Covid-19's impact on GDP or certain industries.

\section{Kaynakça}

Acar, A., Nemutlu, E., Gürhan, G., \& Liman, V. (2004). Hacettepe Üniversitesi Eczacılık Fakültesi Araştırma Görevlilerinin İş Memnuniyeti ve Bunu Etkileyen Faktörler. Hacettepe Üniversitesi Eczacılık Fakültesi Dergisi, 24(2), 95-106.

Alam, K., Ali, A., Ali, N., \& Zaman, G. (2014). Organizational Justice, Task Enjoyment, Leadership style and Organizational Culture as Strategies for Reduction of Social Loafing. Abasyn University Journal of Social Sciences, 7(1), 77-99.

Balc1, O. (2016). Ilköğretim okullarında görev yapan öğretmenler ve yöneticilerin örgütsel sinizm, kendini işe verememe (presenteizm) ve sosyal kaytarma arasindaki ilişkinin incelenmesi (Arnavutköy Illçesi Örneği). Doktora Tezi. İstanbul: İstanbul Arel Üniversitesi.

Baş, T. (2002). Öğretim Üyelerinin İş Tatmin Profillerinin Belirlenmesi, DEÜ İktisadi ve İdari Bilimler Fakültesi Dergisi, 17(2), 19-37.

Budak, G., \& Sürgevil, O. (2005). Tükenmişlik ve Tükenmişliği Etkileyen Örgütsel Faktörlerin Analizine İlişkin Akademik Personel Üzerinde Bir Uygulama. DEÜ İktisadi ve İdari Bilimler Fakültesi Dergisi, 2, 95108.

Candan, H., \& İnce, M. (2016). Siber Kaytarma ve Örgütsel Bağlılık Arasındaki İlişkinin İncelenmesine Yönelik Emniyet Çalışanları Üzerine Bir Araştırma. Niğde Üniversitesi İktisadi ve İdari Bilimler Dergisi, 9(1), 229235.

Ceylan, H., Gül, N., \& Öksüz, M. (2016). Sosyal Çalışmacılarda İş Doyumu ve Tükenmişliğe Etki Eden Faktörlerin Sosyal Hizmet Alanlarına Göre Karşılaştırmalı İncelenmesi. Yalova Üniversitesi Sosyal Bilimler Dergisi, 11, 43-69.

Crawford, G., \& Williams, C. (1985). The analysis of subjective judgment matrices. Project Air Force Report Prepared for the United States Air Force, 1-34.

Çelikten, M. (2003). Akademisyenlerin Mesleki Yardımlaşması: Erciyes Üniversitesi Örneği. Amme Ídaresi Dergisi, 36(2), 101-121.

Demirel, Y. (2009). Örgütsel Adaletin Yönetici-Çalışan İlişkileri Üzerine Etkisi: Farklı Sektör Çalışanlarına Yönelik Bir Araştırma. Sosyal ve Ekonomik Araştırmalar Dergisi, 17, 137-154.

Doğan, A., Bozkurt, S., \& Demir, R. (2012). Sosyal Kaytarma Davranışı İle Algılanan Görev Görünürlüğü Arasındaki İlişkinin İncelenmesine Yönelik Bir 
Araştırma. SÜ İBF Sosyal ve Ekonomik Araştırmalar Dergisi, 244, 53-79.

Dong, Q., \& Cooper, O. (2016). A Peer To Peer Dynamic Adaptive Consensus Reaching Model For The Group Ahp Decision Making. European Journal of Operational Research, 250(2), 521-530. http://dx.doi.org/10.1016/j.ejor.2015.09.016

Eikenhout, N.R. (2004). The Effects of Task Structure and Group Target Monetary Incentives on Social Loafing, Dissertation for the Degree of Doctor of Philosophy: Department of Psychology. USA: Western Michigan University.

Etemadi, M., Darab, M., Khorasani, E., Moradi, F., \& Vazirinasab, H. (2015). Social loafing among nurses and its relation with organizational justice. International Journal Education Psychologic Researches, 1, 125-130.

Gencel, U. (2001). Yükseköğretim Hizmetlerinde Toplam Kalite Yönetimi ve Akreditasyon. D.E.Ü. Sosyal Bilimler Enstitüsü Dergisi, 3(3), 164-218.

Gök, G.A., \& Koca, D. (2016). Sağlık Çalışanlarında Hiyerarşi ve Takım Eğiliminin Sosyal Kaytarmaya Etkisi: Isparta İlçe Hastaneleri Örneği. Mehmet Akif Ersoy Üniversitesi Sosyal Bilimler Enstitüsü Dergisi, 17, 354-375.

Haugen, T., Reinboth, M., Hetlelid, K.J., Peters, D.M., \& Hoigaard, R. (2016). Mental Toughness Moderates Social Loafing Ġn Cycle Time-Trial Performance. Research Quarterly For Exerclse And Sport, 87(3), 305310.

Hoigaard, R., \& Ingvaldsen, R.P. (2006). Social Loafing in Interactive Groups: The Effects of Identifiability on Effort and Individual Performance in Floorball. The online Journal of Sport Psychology, 8 (2), 52-63.

Ilgın, B. (2013). Toplumsal Bir Hastalık: Sosyal Kaytarma. Uşak Üniversitesi Sosyal Bilimler Dergisi, 6(3), 238-270.

Ingham, A.G., Levinger, G., Graves, J., \& Peckham, V. (1974). The Ringelmann Effect: Studies of group size and group performance. Journal Of Experimental Social Psychology, 10(4), 371-384.

Kafes, M., \& Kaya, Ş.D. (2017). Sosyal Kaytarma Davranışı Üzerine Yapılmış Çalışmaların İncelenmesi. Türk \& İslam Dünyası Sosyal Araştırmalar Dergisi, 11, 227-245.

Karaman, F., \& Altunoğlu, A. E. (2007). Kamu üniversiteleri öğretim elemanlarının iş tatmini düzeyini etkileyen faktörler. Yönetim ve Ekonomi: Celal Bayar Üniversitesi Iktisadi ve İdari Bilimler Fakültesi Dergisi, 14(1), 109120.

Karau, S. J., \& Hart, J. W. (1998). Group cohesiveness and social loafing: Effects of a social interaction manipulation on individual motivation within groups. Group Dynamics: Theory, Research, and Practice, 2(3), 185-191. http://dx.doi.org/10.1037/10892699.2.3.185

KC, B., Stainback, G. A., \& Chhetri, B. B. K. (2014). Community users' and experts' perspective on community forestry in Nepal: a SWOT-AHP analysis. Forests, Trees and Livelihoods, 23(4), 217-231. https://doi.org/10.1080/14728028.2014.929982

Kesen, M. (2015). Psikolojik güçlendirme çalışanların sosyal kaytarma davranıșlarını azaltır mı?. Journal of Yaşar University, 10(38), 6531-6540.

Koçel, T. (2014). Işsletme Yöneticiliği. İstanbul: Beta Yayınevi.

Latane, B., Williams, K., \& Harkins, S. (1979). Many Hands Make Light the Work: The Causes and Consequences of Social Loafing. Journal of Personality and Social Psychology, 37(6), 822-832.

Öge, H.S., \& Kurnaz, G. (2017). Presenteeism İle Sosyal Kaytarma Arasındaki İlişki: Otomotiv İşletmesinde Bir Araştırma. International Journal of Academic Value Studies (Javstudies), 3(16), 115-129.

Özmutaf, N. M. (2007). Örgütlerde Bireysel Performans Unsurları ve Çatışma. C.Ü. İktisadi ve Idari Bilimler Dergisi, 8(2), 41-60.

Pabico, J.P., Hermocilla, J.A.C., Galang, J.P.C., \& De Sagun, C.D. (2008). Perceived Social Loafing in Undergraduate Software Engineering Teams. Philippine Information Technology Journal, 1(2), 22-28.

Piezon, S. L., \& Ferree, W. D. (2008). Perceptions of social loafing in online learning groups: A study of public university and US Naval War College students. The International Review of Research in Open and Distributed Learning, 9(2), 1-17. http://dx.doi.org/10.19173/irrodl.v9i2.484

Podvezko, V. (2009). Application of ahp technique. Journal of Business Economics and Management, 10(2), 181189.

Saaty, T. L. (1991). Some mathematical concepts of the analytic hierarchy process. Behaviormetrika, 18(29), 1-9.

Saaty, T. L., \& Zoffer, H. J. (2012). A New Approach to the Middle East Conflict: The Analytic Hierarchy Process. Journal of Multi-Criteria Decision Analysis, 19,201-225.

Schippers, M.C. (2014). Social Loafing Tendencies and Team Performance: The Compensating Effect of Agreeableness and Conscientiousness. Academy of Management Learning \& Education, 1, 62-81.

Simms, A., \& Nichols, T. (2014). Social Loafing: A Review of the Literature. Journal of Management Policy and Practice, 15(1), 58-67.

Supçiller, A. A., \& Çapraz, O. (2011). Ahp-topsıs yöntemine dayalı tedarikçi seçimi uygulaması. Istanbul Üniversitesi Iktisat Fakültesi Ekonometri ve Istatistik Dergisi, 13, 122.

Surapati, P., \& Mukhopadhyaya, D. (2011). Grey relational analysis based intuitionistic fuzzy multi-criteria group decision making approach for teacher selection in higher education. International Journal of Computer Applications, 34(10), 21-29.

Şeşen, H., \& Kahraman, Ç.A. (2014). İş Arkadaşlarının Sosyal Kaytarmasının, Bireyin İş Tatmini, Örgütsel Bağlılık ve Kendi Kaytarma Davranışlarına Etkisi. İş ve Insan Dergisi, 1, 43-51. 
Tan, H.H., \& Tan, M.L. (2008). Organizational citizenship behavior and social loafing: The role of personality, motives, and contextual factors. The Journal of Psychology, 142(1),89-108.

Thompson, R.B., \&Thornton, B. (2014). Gender and Theory of Mind in Preschoolers' Group Effort: Evidence for Timing Differences Behind Children's Earliest Social Loafing. The Journal of Social Psychology, 154, 475479. https://doi.org/10.1080/00224545.2014.933763

Tolukan, E., Bayrak, M., \& Karacan Doğan, P. (2017). Antrenörlerin Sosyal Kaytarma Algılarının İncelenmesi. Gaziantep Üniversitesi Spor Bilimleri Dergisi, 2(1), 113.

Triantaphyllou, E., \& Mann, S. H. (1995). Using the analytic hierarchy process for decision making in engineering applications: some challenges. International Journal of Industrial Engineering: Applications and Practice, 2(1), 35-44.
Uslu, Y.D., \& Çavuş, M.F. (2014). Örgütsel Adalet ve Kaytarma Davranışları. Ordu Üniversitesi Sosyal Bilimler Araştırmaları Dergileri, 7, 51-54.

Uysal, H. T. (2016). Örgütlerde Sosyal Kaytarma Algısının Çalışanların Tükenmişlik Duygusuna Etkisi. 3. Ulusal Meslek Yüksekokullarl Sosyal ve Teknik Bilimler Kongresi, 732-743.

Ünal, Ö. F. (2011). Analitik Hiyerarşi Prosesi ve Personel Seçimi Alanında Uygulamaları. Akdeniz Üniversitesi Uluslararası Alanya Iş̧letme Fakültesi Dergisi, 3 (2), 1838.

Williams, K.D., \& Karau, S.J. (1991). Social Loafing and Social Compensation: The Effects of Expectations of CoWorker Performance. Journal of Personality and Social Psychology, 61 (4), 570-581.

Williams, K.D., \& Karau, S.J. (1993). Social Loafing: A Meta Analytic Review and Theoritical Integration. Journal of Personality and Social Psychology, 65(4), 681-706. 